\title{
Progress Report: Cofiring Projects for Willow Island and Albright Generating Stations
}

Prepared by:

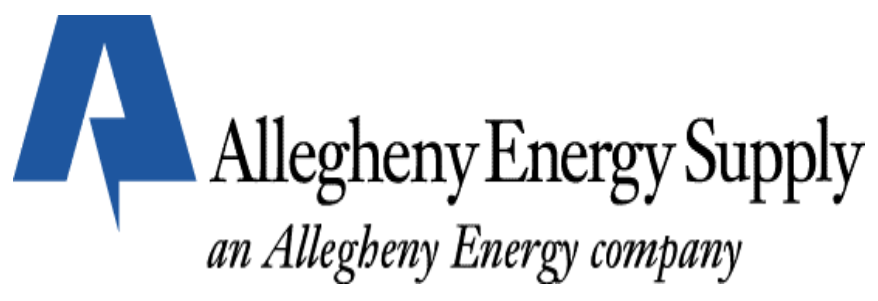

October, 2001 


\title{
DESIGNING AN OPPORTUNITY FUEL WITH BIOMASS AND TIRE-DERIVED FUEL FOR COFIRING AT WILLOW ISLAND GENERATING STATION AND COFIRING SAWDUST WITH COAL AT ALBRIGHT GENERATING STATION
}

\author{
Quarterly Technical Report \\ Reporting Period: 7/1/2001 - 9/30/2001
}

Authors: K. Payette and D. Tillman

Report Issue Date: October 2001

DE-FC26-00NT40894

\author{
Allegheny Energy Supply Co., LLC \\ 4350 Northern Pike \\ Monroeville PA 15146-2841
}


"This report was prepared as an account of work sponsored by an agency of the United States Government. Neither the United States Government no any agency thereof, nor any of their employees, makes any warranty, express of implied, or assumes any legal liability of responsibility for the accuracy, completeness, or usefulness of any information, apparatus, product, or process disclosed, or represents that its use would not infringe privately owned rights. Reference herein to any specific commercial product, process, or service by trade name, trademark, manufacturer, or otherwise does not necessarily constitute or imply its endorsement, recommendation, or favoring by the United States Government or any agency thereof. The views and opinions of authors expressed herein do not necessarily state or reflect those of the United States Government or any agency thereof." 


\begin{abstract}
During the period July 1, 2001 - September 30, 2001, Allegheny Energy Supply Co., LLC (Allegheny) continued construction of the Willow Island cofiring project, completed the installation of the fuel storage facility, the fuel receiving facility, and the processing building. All mechanical equipment has been installed and electrical construction has proceeded. During this time period significant short term testing of the Albright Generating Station cofiring facility was completed, and the 100-hour test was planned for early October. The testing demonstrated that cofiring at the Albright Generating Station could contribute to a "4P Strategy"-reduction of $\mathrm{SO}_{2}, \mathrm{NO}_{\mathrm{x}}$, mercury, and greenhouse gas emissions.

This report summarizes the activities associated with the Designer Opportunity Fuel program, and demonstrations at Willow Island and Albright Generating Stations. It details the construction activities at both sites along with the combustion modeling at the Willow Island site.
\end{abstract}




\section{CONTENTS}

$\underline{\text { Page }}$

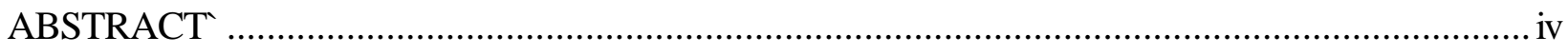

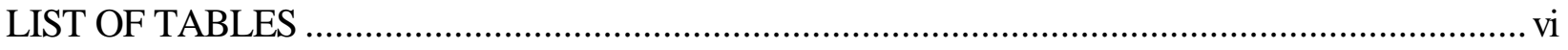

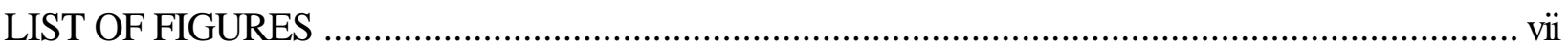

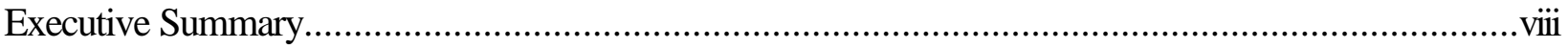

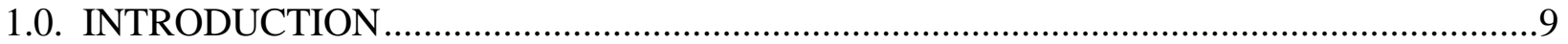

1.1. The Willow Island Demonstration........................................................................... 9

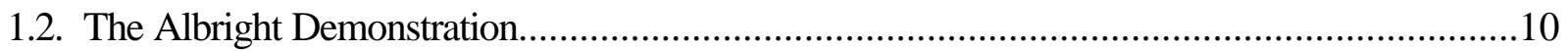

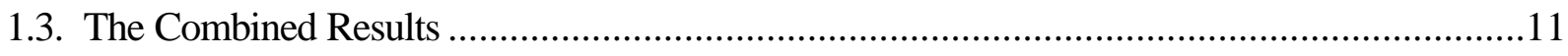

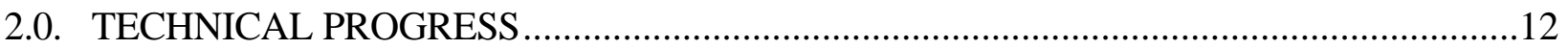

2.1. Technical Progress On Combustion at Willow Island Generating Station.............................12

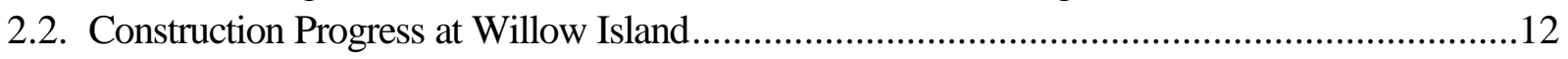

2.3. Technical Progress on the Albright Demonstration.......................................................16

2.4. Expected Technical Progress During the SIXTH Project Quarter ......................................23 


\section{LIST OF TABLES}

$\underline{\text { Page }}$

Table 1. Probability that equation 1 , or any individual term, occurred randomly ............................21

Table 2. Anticipated Progress at Willow Island and Albright Demonstration Sites ...........................23 


\section{LIST OF FIGURES}

Page

Figure 1. Overview of the construction of the processing building at Willow Island Generating Station. .13

Figure 2. Picture of the live bottom bin with associated stairs and walkways at Willow Island

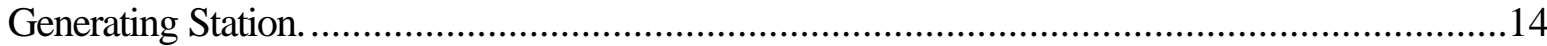

Figure 3. The inside of the live bottom sawdust storage bin at Willow Island Generating Station.........15

Figure 4. Opacity emissions during testing at Albright Generating Station cofiring tests....................17

Figure 5. Carbon monoxide emissions at Albright Generating Station cofiring tests .........................18

Figure 6. $\mathrm{SO}_{2}$ emissions as a function of cofiring percentage, measured on a mass basis at

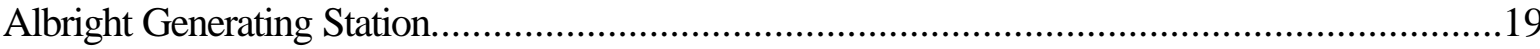

Figure 7. $\mathrm{SO}_{2}$ emissions as a function of cofiring percentage, measured on a heat input basis at

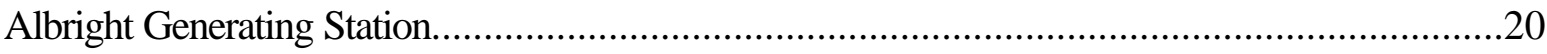

Figure 8. $\mathrm{NO}_{\mathrm{x}}$ reduction during cofiring testing at the Albright Generating Station...........................21 


\section{EXECUTIVE SUMMARY}

The Fifth Quarter of the USDOE-Allegheny Energy Supply Co., LLC (Allegheny) Cooperative Agreement, July 1, 2001 through September 30, 2001, was characterized by combustion modeling and project construction activities at both the Willow Island and Albright sites. Technical work that proceeded during the fourth quarter of the cooperative agreement included the following:

- At Willow Island Generating Station, all mechanical construction is complete. The fuel receiving system has been installed, the fuel screening system has been installed, the walking floor bin has been installed, and all conveyors have been installed. The processing building has been erected. Electrical construction has been started and is well underway.

- Construction was completed at the Albright Generating Station site during the second calendar quarter of 2001. Extensive detailed short-term testing was conducted during the months of May, June, and July_including baseline testing and system testing up to 10 percent (mass basis). These tests were analyzed documenting the ability of cofiring to reduce $\mathrm{SO}_{2}, \mathrm{NO}_{\mathrm{x}}$, mercury, and greenhouse gas emissions. Planning for a 100-hr test was completed.

Progress anticipated for the sixth quarter of this cooperative agreement-October 1, 2001 through December 31, 2001-includes completion of construction at the Willow Island Generating Station, shakedown of that facility, and initial short-term testing at this location. Progress anticipated also includes completion of the 100-hr test at Albright Generating Station, completion of the 720 test hours on the unit, and analysis of the data resulting from the test program. 


\subsection{INTRODUCTION}

Cofiring - the firing of two dissimilar fuels at the same time in the same boiler - has been proposed for using biomass in coal-fired utility boilers. In practice, this cofiring introduces a family of technologies rather than a single technology. The family of technologies includes blending the fuels on the coal pile or coal belt, and feeding them simultaneously to any processing (e.g., crushing and/or milling) systems on their way to the boiler; preparing the biofuels separately from the coal and introducing them into the boiler in a manner that does not impact fossil fuel delivery; or converting the solid biofuels to some other fuel form (e.g., producer gas) for firing in a coal-fired or natural gas-fired installation. The Allegheny project is designed to demonstrate both direct combustion approaches to cofiring.

\subsection{THE WILLOW ISLAND DEMONSTRATION}

Allegheny Energy Supply, LLC will demonstrate blending wood waste and tire-derived fuel to create a new opportunity fuel for cofiring in cyclone boilers, and integrating this fuel combination with a separated overfire air system for maximum $\mathrm{NO}_{\mathrm{x}}$ management. This project also will demonstrate the use of biomass-TDF blends to reduce $\mathrm{SO}_{2}$ and fossil $\mathrm{CO}_{2}$ emissions along with trace metal emissions. The demonstration will occur at Willow Island Generating Station Boiler \#2. It is a 188-MW $\mathrm{MW}_{\mathrm{e}}$ cyclone boiler operated in a pressurized mode and equipped with a "hot side" electrostatic precipitator (ESP). This demonstration, located in Willow Island, WV, has numerous unique features to significantly advance cofiring technology. Allegheny Energy, using Foster Wheeler Development Corporation, has completed a feasibility study for the project and plans to move directly into Phase II - construction and operation of the demonstration system.

Cofiring of wood wastes with coal has been demonstrated as an effective means for using biomass in cyclone boilers; demonstrations have occurred at the Allen Fossil Plant of TVA, the Michigan City Generating Station of NIPSCO, and the Bailly Generating Station (BGS) of NIPSCO. In these demonstrations, $\mathrm{NO}_{\mathrm{x}}, \mathrm{SO}_{2}$, and fossil-based $\mathrm{CO}_{2}$ emissions reductions occurred. In each case, the volatility of the wood waste created the mechanism for $\mathrm{NO}_{\mathrm{x}}$ reduction, while the use of a sulfur-free fuel reduced $\mathrm{SO}_{2}$ emissions. Testing at $\mathrm{BGS}$ opened a new area of investigation: designing blends of opportunity fuels to optimize the impacts of cofiring. At BGS, urban wood waste is mixed with petroleum coke at a specified blend to optimize $\mathrm{NO}_{\mathrm{x}}$ emissions management while accomplishing the goals of fossil $\mathrm{CO}_{2}$ emissions reductions. The $\mathrm{NO}_{\mathrm{x}}$ emissions reductions at $\mathrm{BGS}$ are $\sim 30$ percent when firing the designed opportunity fuel blend. 
The Willow Island demonstration will blend sawdust with TDF to create a new opportunity fuel for cofiring in a cyclone boiler equipped with a separated overfire air system. This demonstration will create a second opportunity fuel blend that maximizes $\mathrm{NO}_{\mathrm{x}}$ emissions reductions from the combustion process and that can be integrated into the overall $\mathrm{NO}_{\mathrm{x}}$ emissions management strategy using overfire air. At the same time, $\mathrm{SO}_{2}$ emissions will be reduced along with fossil $\mathrm{CO}_{2}$ emissions and heavy metal emissions. The Willow Island plant "hot-side" ESP requires the use of a sodium additive to enhance the resistivity of the flyash particles. This demonstration will examine the potential of biofuel cofiring to obviate the need for such additives in the control of particulates and opacity-capitalizing upon the potassium and sodium content of the biomass ash.

The demonstration program involves optimizing the sawdust-TDF-coal blend for maximum impact in the cyclone combustion process. Further, it involves optimizing this blend to capitalize upon the overfire air system for $\mathrm{NO}_{\mathrm{x}}$ management.

It is estimated that the project will fire at least 10 percent wood waste, along with about 10 percent TDF in the project.

While this demonstration involves integrating past successful programs, it provides a significant enhancement of cofiring and the use of biomass. If successful, it will be the first demonstration where cofiring has been explicitly integrated into an overall $\mathrm{NO}_{\mathrm{x}}$ control strategy as a significant contributor. Further, if successful, it provides a means for cyclone boiler owners and operators to consider $\mathrm{NO}_{\mathrm{x}}$ management strategies other than end-of-pipe solutions or expensive fossil-based combustion strategies to achieve compliance with current and proposed regulations.

Further, this will be the first cofiring demonstration where the boiler is equipped with a "hot side" electrostatic precipitator - an ESP installed between the economizer and the air heater rather than after the air heater. Such "hot side" ESP's conventionally use sodium additives to improve the resistivity of the flyash and enhance its capture. Biomass, with its concentrations of potassium and sodium, may reduce or eliminate the need for such additives. This demonstration will address that condition and, as a consequence, advance the use of cofiring in coal-fired boilers.

\subsection{THE ALBRIGHT DEMONSTRATION}

The Albright Generating Station demonstration provides a means for comparing the $\mathrm{NO}_{\mathrm{x}}$ reduction results obtained at Willow Island Generating Station - in a cyclone boiler - to those that can be obtained in a pulverized coal boiler. The Albright Generating Station Boiler \#3 is a $140 \mathrm{MW}_{\mathrm{e}}$ boiler, comparable in capacity to the Willow Island boiler. It burns a similar eastern bituminous coal. Of critical importance, the Albright boiler is equipped with a low- $\mathrm{NO}_{\mathrm{x}}$ firing system including a separated overfire air system. 
The Electric Power Research Institute (EPRI) has developed a demonstration of sawdust cofiring in a PC boiler at the Seward Generating Station. A favorable biomass fuel supply potential and the favorable technology potential has led Allegheny to decide to relocate the cofiring demonstration to the Albright Generating Station. The relocation of the separate injection demonstration from Seward Generating Station to Albright provides opportunities to extend the knowledge base concerning cofiringcapitalizing upon the configuration of Albright Boiler \#3. Specifically cofiring has not been applied to a generating station equipped with low $\mathrm{NO}_{\mathrm{x}}$ firing separated overfire air system. In relocating the demonstration from Seward to Albright, it is prudent to capitalize upon such an opportunity.

Given this opportunity, Allegheny and Foster Wheeler have accomplished the following:

- Disassembly and removal of the existing demonstration from the Seward site,

- Supply and install of two biomass injectors in Albright Boiler \#3

- Installation of piping sufficient to transport sawdust to the biomass injectors at Albright Boiler \#3

- Installation of the process equipment removed from Seward Generating Station to the Albright Generating Station

- Construction of a steel building to house the process equipment associated with the demonstration of separate injection cofiring

- Demonstration of cofiring at Albright, providing emissions data for comparison to the Willow Island demonstration.

\subsection{THE COMBINED RESULTS}

The combination of the Willow Island demonstration at the cyclone boiler and the comparative data developed at the Albright demonstration in a tangentially-fired pulverized coal boiler will provide definitive data concerning the emissions reduction potential of biomass cofiring in units already equipped with low $\mathrm{NO}_{\mathrm{x}}$ firing systems. As such, these data will help define the potential, and limits, of biomass cofiring as an emissions reduction strategy. At the same time these demonstrations will provide a means for evaluating biomass cofiring as a cost-effective strategy for voluntary fossil $\mathrm{CO}_{2}$ emissions reductions. Finally these projects will demonstrate additional environmental benefits of cofiring. 


\subsection{TECHNICAL PROGRESS}

Overall progress has included concluding contract negotiations with Foster Wheeler and, consequently, with the specialty subcontractors. With these contracts in place, progress has been significant on both projects.

\subsection{TECHNICAL PROGRESS ON COMBUSTION AT WILLOW ISLAND GENERATING STATION}

Technical progress on combustion at Willow Island focused upon the initial baseline testing at the unit. Baseline testing included acquiring operating data from the control room along with CEMS data, fuel samples, flyash samples, and bottom ash samples. Data taken documented the operating and environmental characteristics of the plant useful for analyzing the cofiring and triburn tests.

\subsection{CONSTRUCTION PROGRESS AT WILLOW ISLAND}

The cofiring system being installed at Willow Island is based upon blending the sawdust with TDF and coal in the bunkers, and feeding the blended fuel to the cyclones. Sawdust is received in walking floor vans. They deposit the sawdust into a receiving hopper. From there the sawdust is conveyed to a disc screen for processing. The screen will produce a product at $\left\langle 1 / 4^{\prime} \times 0\right.$ " particle size for maximum $\mathrm{NO}_{\mathrm{x}}$ benefit. Screened product is conveyed to a large live bottom bin for storage. It is reclaimed from the bin and deposited on the main conveyor belt feeding coal to the bunkers. Blending the sawdust with the

coal and TDF is accomplished by 3 transfer points and by passing the blend through the secondary crushers. Oversized product from the screen is sent to a small grinder that reduces the particles to $<1 / 4$ ' and then integrates them with the product of the disc screen. Figures 1 - 3 show the construction as of August 31, 2001. Considerable progress has been made during September, 2001. 


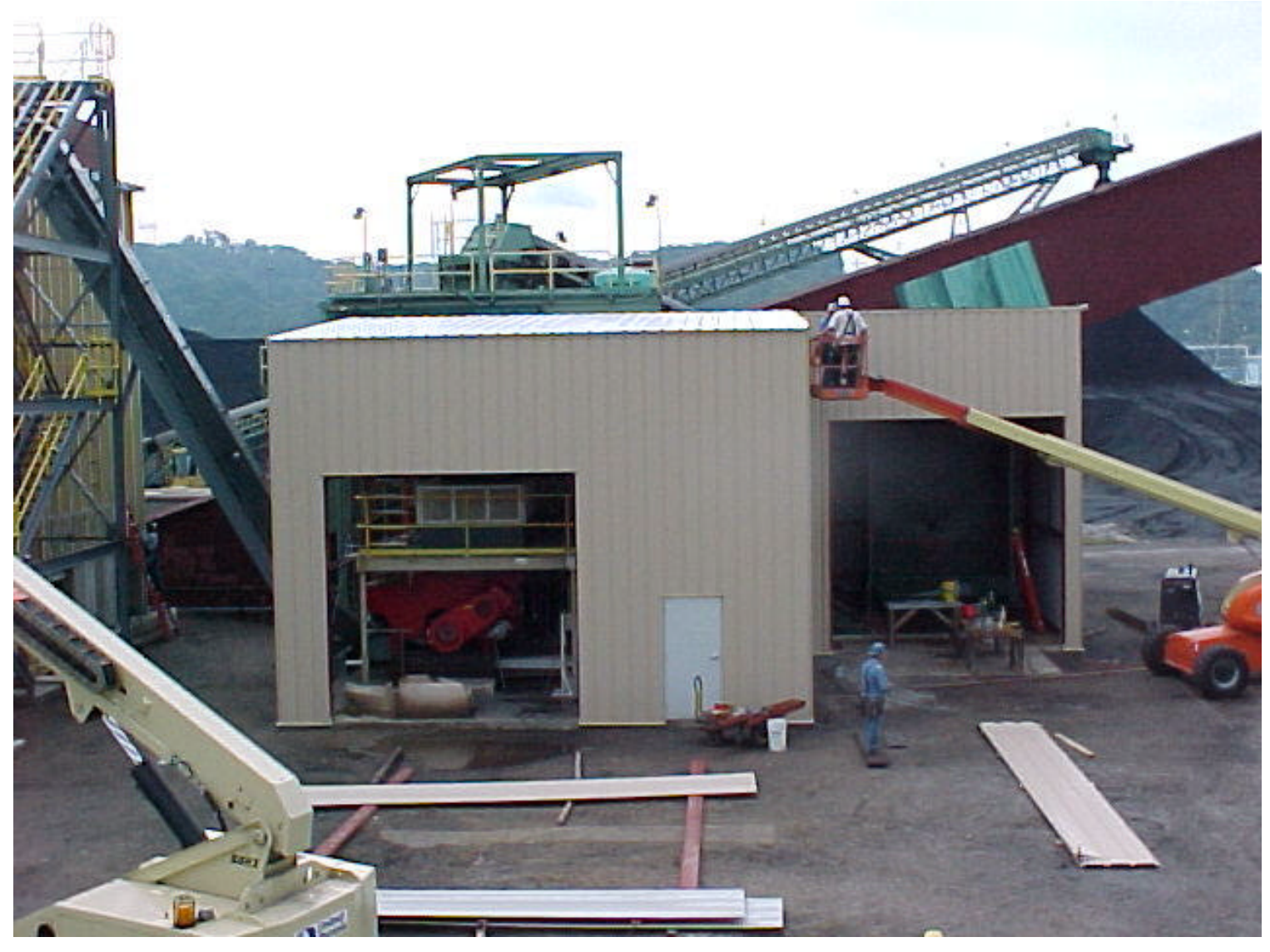

Figure 1. Overview of the construction of the processing building at Willow Island Generating Station.

The truck receiving hopper is center-right, inside the building. The disc screen and oversized material grinder is in the center of the building through the oversized door on the left. The outfeed conveyor transporting the sawdust to the live bottom bin is on the left side of the building. The corner of the live bottom bin can be seen at the extreme left of the picture. 


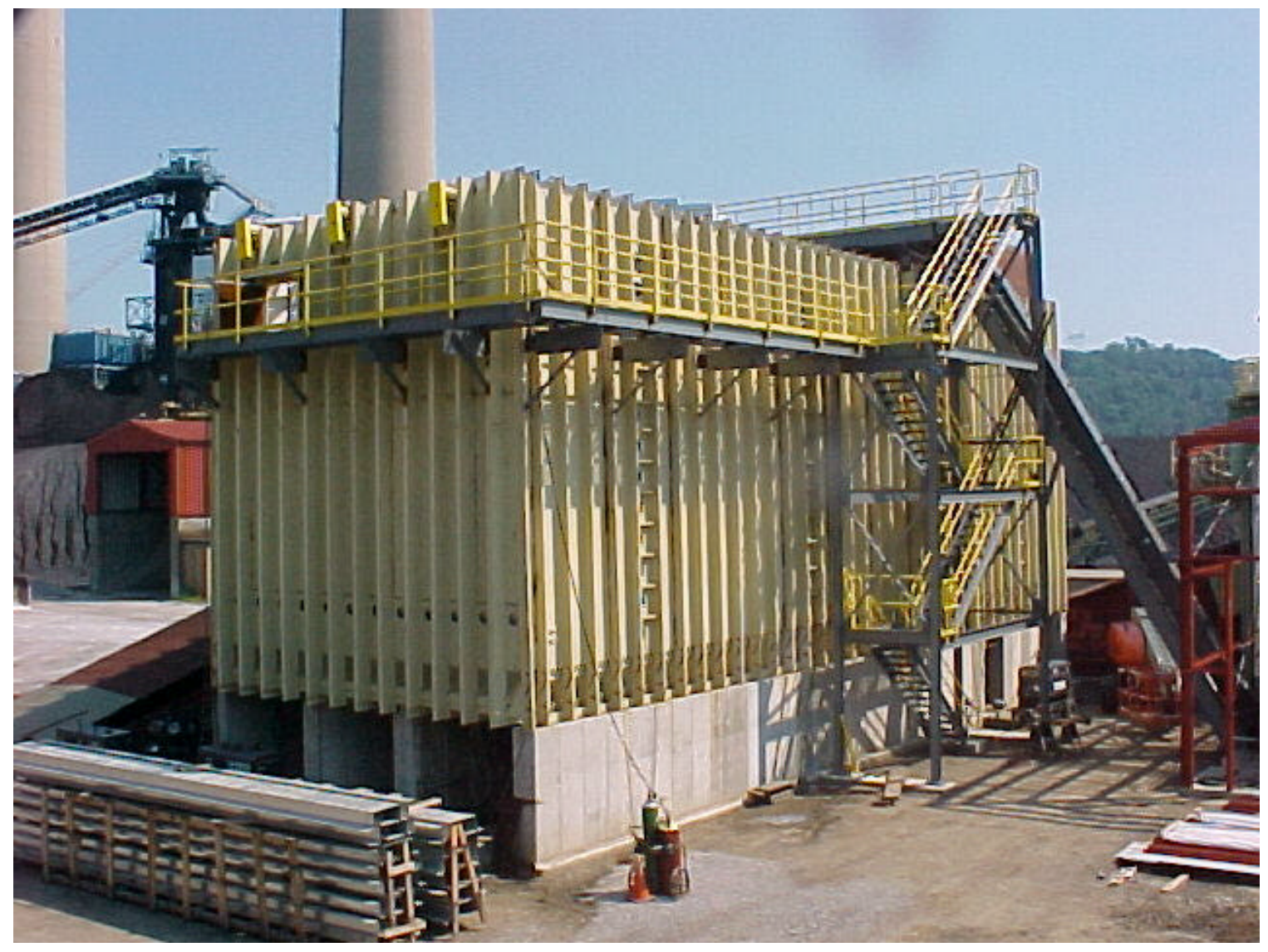

Figure 2. Picture of the live bottom bin with associated stairs and walkways at Willow Island Generating Station. 


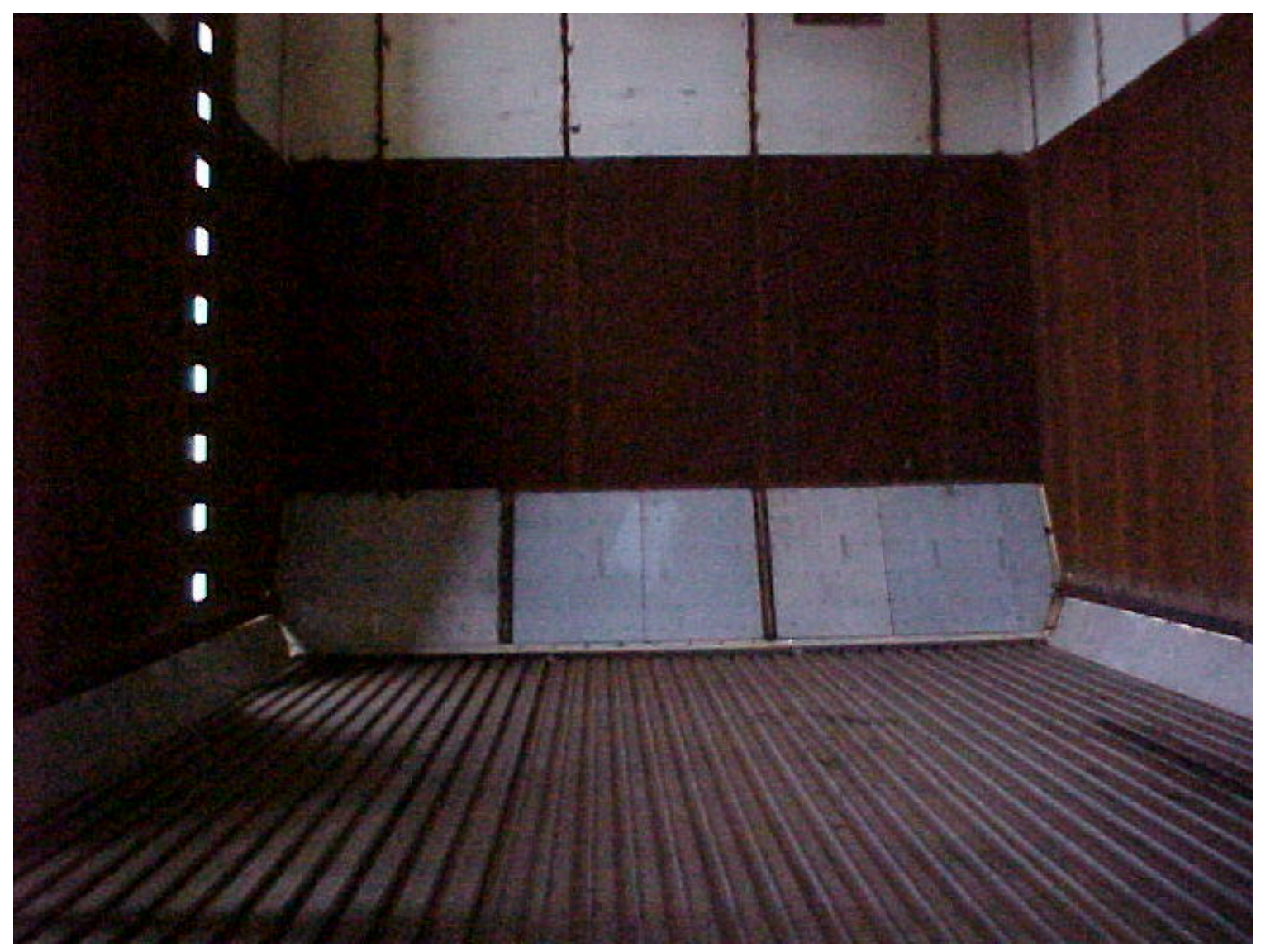

Figure 3. The inside of the live bottom sawdust storage bin at Willow Island Generating Station. 


\subsection{TECHNICAL PROGRESS ON THE ALBRIGHT DEMONSTRATION}

The Albright construction has been completed to the satisfaction of Allegheny Energy Supply Co., LLC, and testing has commenced. During the short term testing, 68 test hours were completed at loads up to $130 \mathrm{MW}_{\mathrm{e}}$ (net) or $138 \mathrm{MW}_{\mathrm{e}}$ (gross). The results of the testing indicated that the cofiring project could work synergistically with the separated overfire air (SOFA) system, and could be used as a component in a " $4 \mathrm{P}$ " Strategy - a strategy to reduce emissions of the following categories:

- $\quad$ Sulfur dioxide $\left(\mathrm{SO}_{2}\right)$

- Oxides of Nitrogen $\left(\mathrm{NO}_{\mathrm{x}}\right)$

- Mercury

- Greenhouse gases (particularly fossil-based $\mathrm{CO}_{2}$ )

From May 30, 2001 through July 27, 2001, detailed testing was conducted at the Albright Generating Station demonstration. Cofiring levels ranged from 0 to 10 percent on a mass basis, or 4.7 percent on a heat input basis. Parameters varied during these tests included the following:

- Load, measured in either gross $\mathrm{MW}_{\mathrm{e}}$ or in main steam flow $(\mathrm{kg} / \mathrm{sec})$, ranging from 90 $\mathrm{MW}_{\mathrm{e}}$ to $130 \mathrm{MW}_{\mathrm{e}}$ (net) or $97-138 \mathrm{MW}_{\mathrm{e}}$ (gross)

- Excess $\mathrm{O}_{2}$, measured in total percentage (rather than dry percentage) at the furnace exit, focusing on the $2.5-4.9$ percent range

- Cofiring percentage as discussed above

- SOFA damper position, ranging from a very closed approach to a wide open approach

Operationally, cofiring did not impact load. Further, it did not cause a significant increase in induced draft (ID) fan amps - suggesting a potential limitation to cofiring at any level. The fact that fan amps were not impacted was particularly significant in that testing occurred on some very hot days (e.g., days with temperatures $>90^{\circ} \mathrm{F}$ ). It should also be noted that there are three rows of SOFA dampers, and these can be opened independently with damper positions ranging from 0 to 100 percent. Testing occurred over the full range of SOFA damper positions.

Emissions evaluated during these tests included opacity, carbon monoxide $(\mathrm{CO})$, sulfur dioxide $\left(\mathrm{SO}_{2}\right)$, and oxides of nitrogen $\left(\mathrm{NO}_{\mathrm{x}}\right)$. The method for measuring these emissions was the use of the plant CEMS, backed up by portable instrumentation supplied by Foster Wheeler. Data reported here are from the CEMS.

\section{Opacity and CO Emissions Measured at the Albright Generating Station Cofiring Tests}

Opacity and $\mathrm{CO}$ emissions are indicators of combustion completeness as well as measures of pollution. Because the sawdust fired at Albright Generating Station is green-with typically 38 - 45 percent 
moisture - the practice of cofiring can reduce furnace gas residence times impacting these emissions. At the same time, however, the volatility of the sawdust is such that ignition occurs more rapidly with the sawdust than the coal, and the rates of both devolatilization and char oxidation are higher for sawdust than for eastern bituminous coal.

The opacity and $\mathrm{CO}$ emissions as a function of cofiring percentage at Albright Generating Station are shown in Figures 4 and 5. Opacity is shown in percentage, and CO emissions are shown in ppmv. Note that cofiring biomass at up to 10 percent (mass basis) did not impact either the opacity or CO emissions.

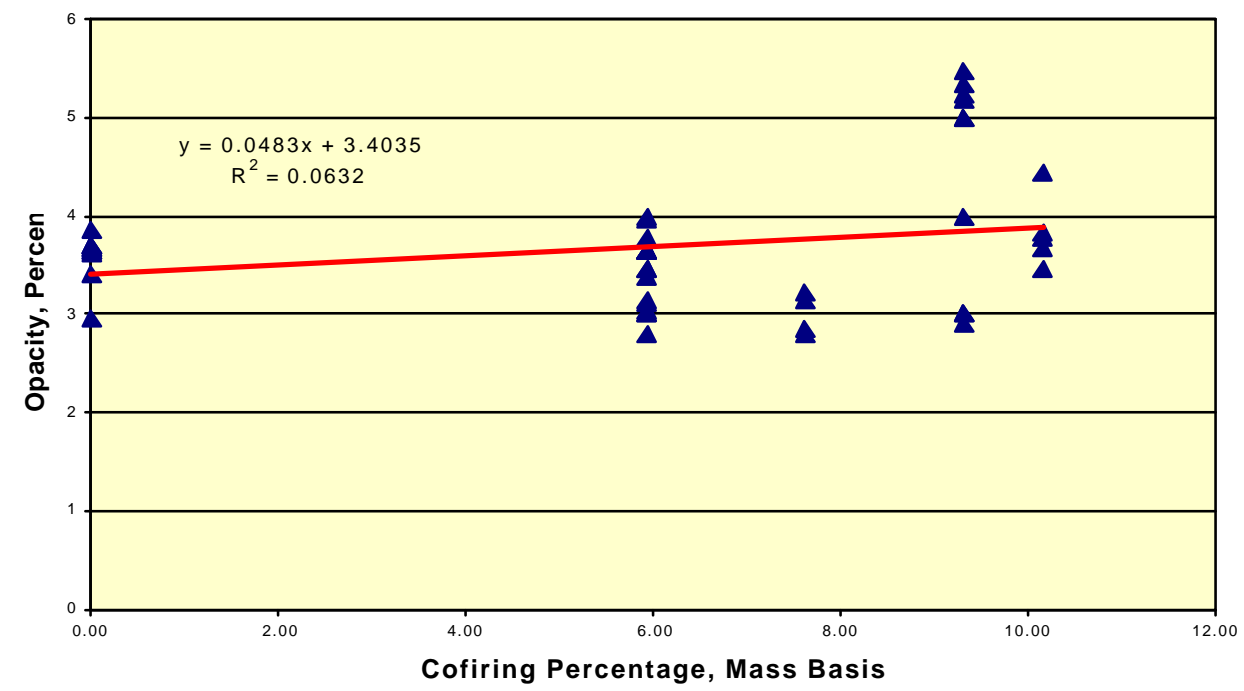

Figure 4. Opacity emissions during testing at Albright Generating Station cofiring tests 


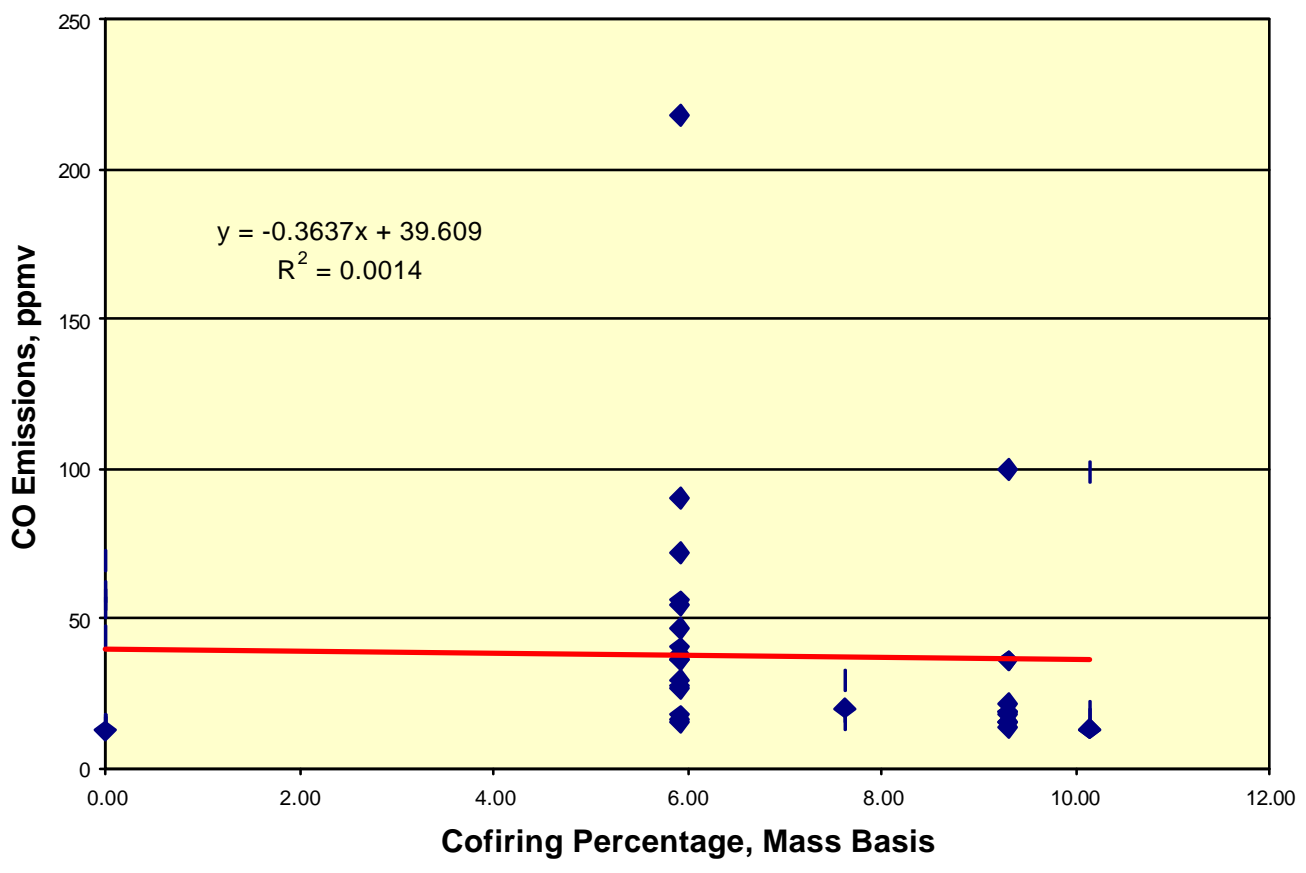

Figure 5. Carbon monoxide emissions at Albright Generating Station cofiring tests

Calculated trend lines are shown on Figures 4 and 5, along with regression equation calculations. Note that the coefficients of determination $\left(r^{2}\right)$ for the trend lines shown are 0.0632 for opacity and 0.0014 for CO. Note, also, the significant amount of scatter in the CO data. While opacity ranged from 2.8 percent to 5.5 percent, $\mathrm{CO}$ emissions ranged from $<10 \mathrm{ppmv}$ to one case where emissions exceeded 200 ppmv - and without regard to cofiring percentage. Note, also, that virtually all CO emissions were $\leq 100$ ppmv. Attempts to correlate opacity and CO emissions to more complex sets of variables proved fruitless. Opacity did trend slightly upward, largely driven by testing during one 4-hour period. For the most part, however, the opacity measurements were between 3 and 4 percent. Further, the slight upward trend was not statistically significant as is shown in Figure 5. The only conclusion that could be drawn was that cofiring — and the sawdust injected into the boiler — did not impact these values either as emissions or as measures of combustion completeness. It is significant to note that unburned carbon (UBC) or loss on ignition (LOI) measured during these tests in both the bottom ash and flyash also did not vary as a function of cofiring. This supports the opacity and $\mathrm{CO}$ data.

\section{Sulfur Dioxide Emissions Measured at the Albright Generating Station Cofiring Tests}

$\mathrm{SO}_{2}$ emissions decreased modestly, as expected, based upon heat input. Figures 6 and 7 illustrate this phenomenon. Note that there is some spread in the data, based upon normal variability in the coal. Note, also, that the decrease is more accurately depicted in terms of cofiring on a heat input basis. 


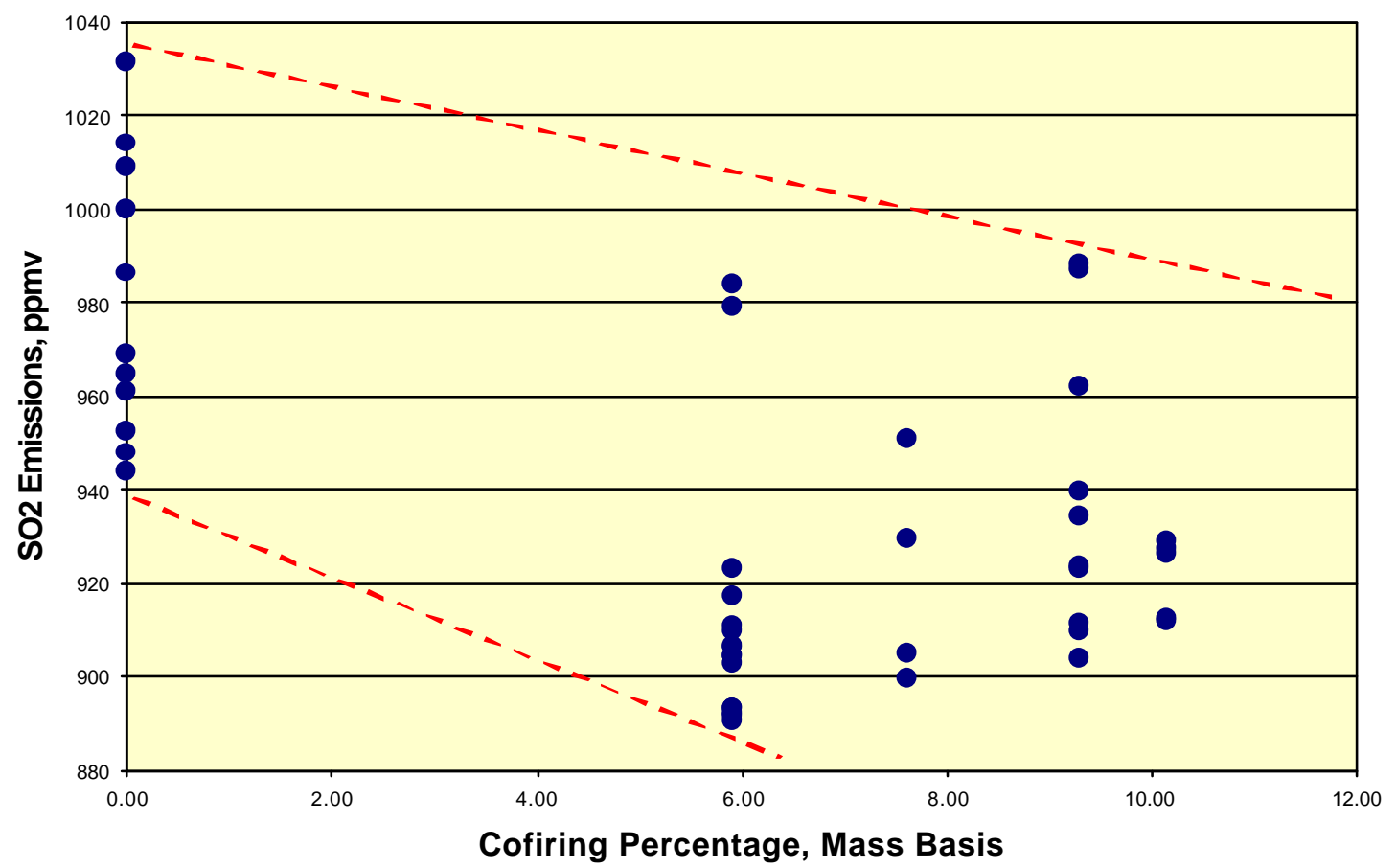

Figure 6. $\mathrm{SO}_{2}$ emissions as a function of cofiring percentage, measured on a mass basis at Albright Generating Station 


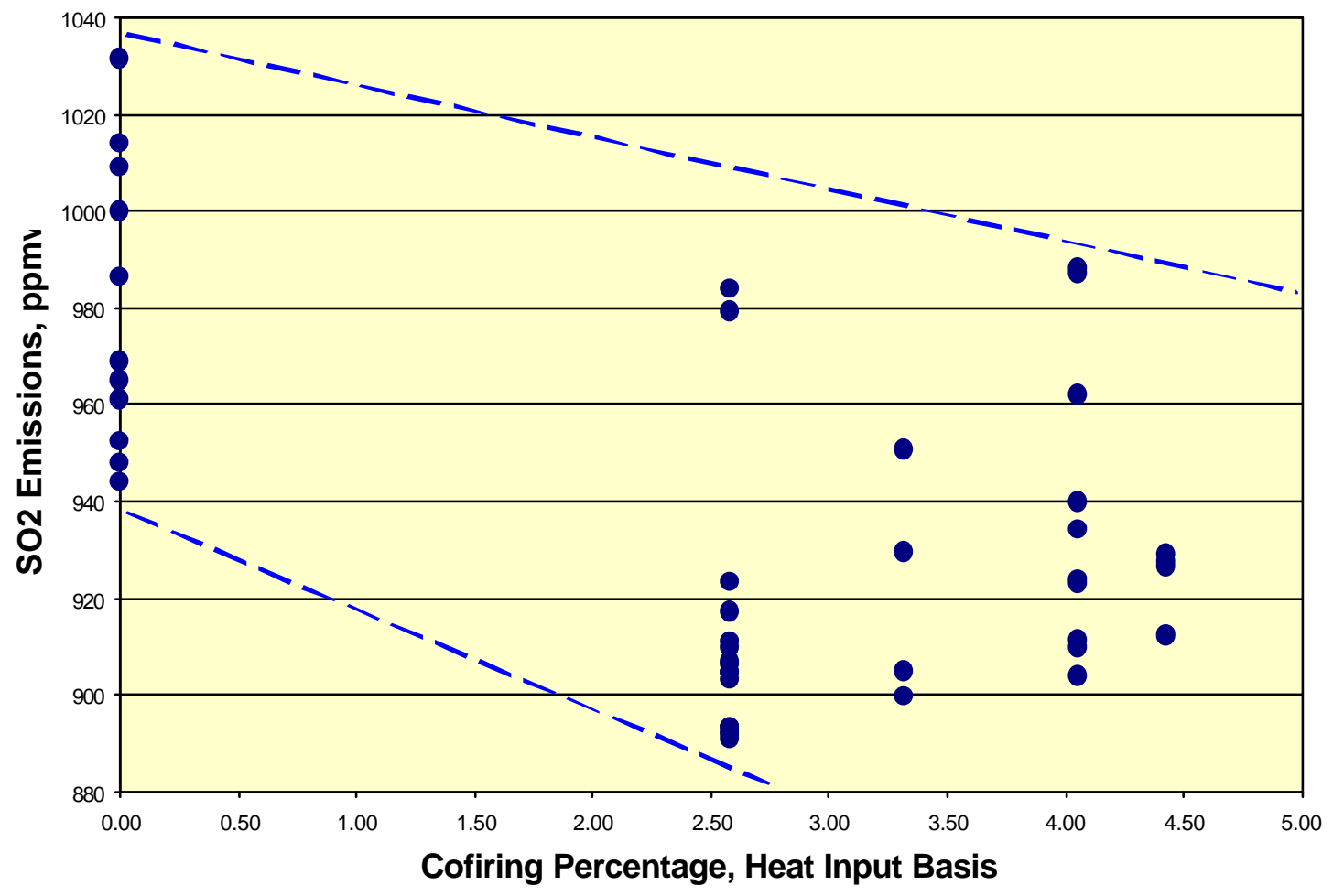

Figure 7. $\mathrm{SO}_{2}$ emissions as a function of cofiring percentage, measured on a heat input basis at Albright Generating Station

The scatter in the data prevents any substantial trend analysis. However the general conclusion that $\mathrm{SO}_{2}$ is reduced as a function of cofiring percentage on a heat input basis, corrected for efficiency impacts, holds.

\section{$\mathrm{NO}_{\mathrm{x}}$ Emissions Measured at the Albright Generating Station Cofiring Tests}

The practice of cofiring at the Albright Generating Station caused a significant reduction in $\mathrm{NO}_{\mathrm{x}}$ emissions measured in $\mathrm{lb} / 10^{6} \mathrm{Btu}$ as shown in Figure 8. Note that there is a significant spread in the data, caused by variations in the parameters identified above: cofiring percentage, excess $\mathrm{O}_{2}$, and SOFA positions. Within the load range tested, load did not appear to be a significant contributor to the formation or control of $\mathrm{NO}_{\mathrm{x}}$. In general, cofiring at 10 percent by mass (4.7 percent by heat input) caused about a 15 percent reduction in $\mathrm{NO}_{\mathrm{x}}$. In other words, for every percent sawdust fired on a heat input basis, $\mathrm{NO}_{\mathrm{x}}$ was reduced by $\geq 3$ percent. NOx emissions were consistently measured as low as $0.26 \mathrm{lb} / 10^{6}$ Btu when cofiring and maximizing the use of the SOFA system. 


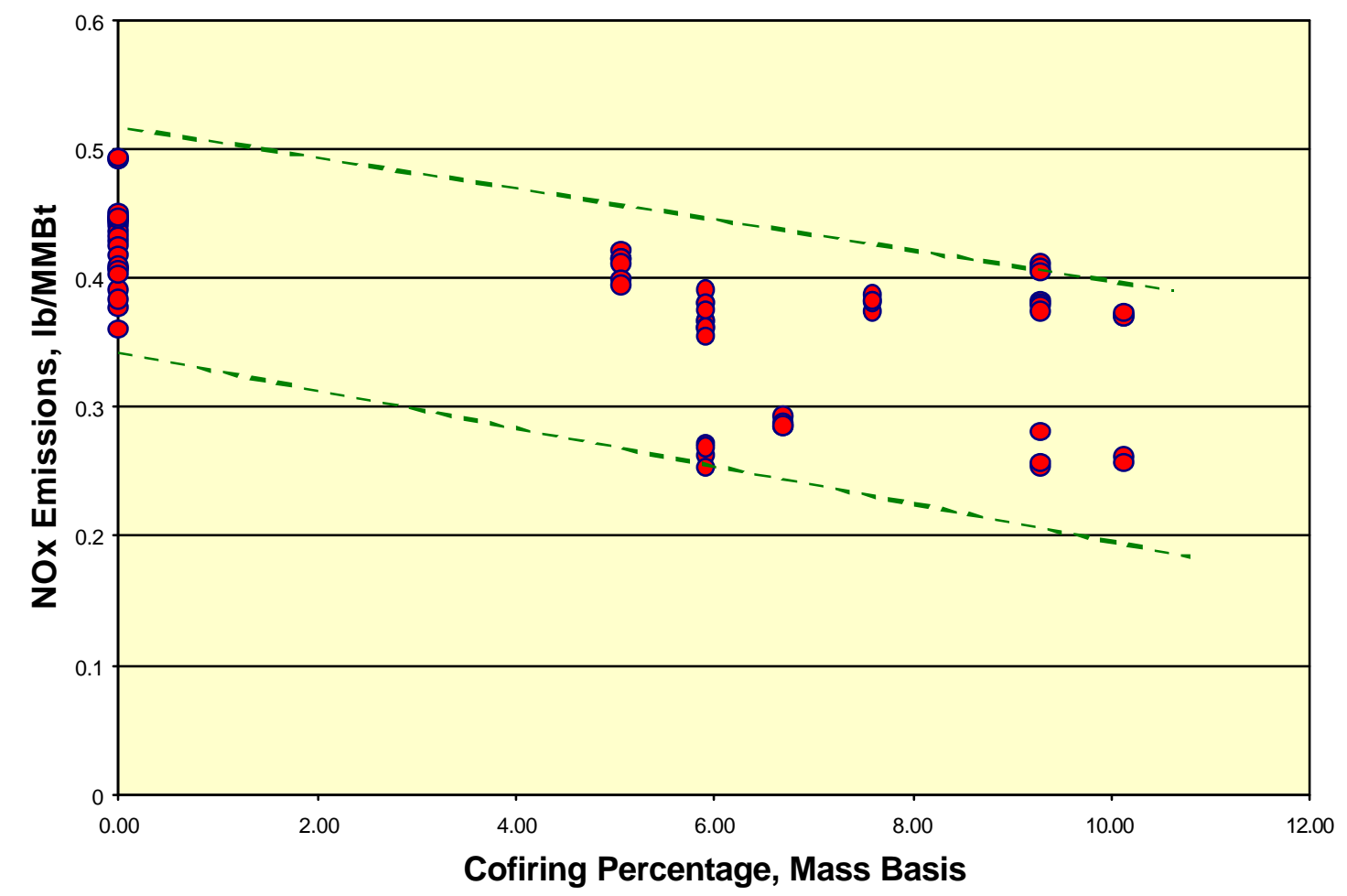

Figure 8. $\mathrm{NO}_{\mathrm{x}}$ reduction during cofiring testing at the Albright Generating Station

The NOx data were converted into a single, robust, regression equation as shown below. The equation, based upon 68 individual data points, and the $r^{2}$ for this equation is 0.873 .

$$
\mathrm{NO}_{\mathrm{x}}\left(\mathrm{lb} / 10^{6} \mathrm{Btu}\right)=0.361-0.0043(\mathrm{~W} \%)+0.0217\left(\mathrm{O}_{2} \%\right)-0.00055(\mathrm{SOFA})[1]
$$

Where $\mathrm{NO}_{\mathrm{x}}$ is measured in $\mathrm{lb} / 10^{6} \mathrm{Btu}, \mathrm{W} \%$ is sawdust percentage in the fuel on a mass basis, $\mathrm{O}_{2} \%$ is the percentage excess oxygen measured at the furnace exit, and SOFA is the total percentage of the three SOFA dampers expressed as percent open. Note that the range of $\mathrm{W}$ terms is $0-10$, the range of $\mathrm{O}_{2} \%$ terms is $2.8-4$, and the range of SOFA terms is $15-240$. This may explain the difference in the coefficients.

Table 1 demonstrates the robustness of this equation. It presents the probabilities that any given calculated value occurs randomly. Any probability $<0.05$ can be considered significant; any probability $<0.01$ can be considered highly significant.

Table 1. Probability that equation 1, or any individual term, occurred randomly

\begin{tabular}{|c|l|l|}
\hline Number & Parameter Evaluated & $\begin{array}{l}\text { Probability of } \\
\text { Randomness }\end{array}$ \\
\hline 1 & Total Equation & $4.17 \times 10^{-28}$ \\
\hline 2 & Intercept & $5.23 \times 10^{-25}$ \\
\hline 3 & Sawdust Percentage & $3.13 \times 10^{-6}$ \\
\hline
\end{tabular}




\begin{tabular}{|l|l|l|}
\hline 4 & Excess O2 Percent & $8.20 \times 10^{-4}$ \\
\hline 5 & SOFA Dampers Percent & $2.58 \times 10^{-22}$ \\
\hline
\end{tabular}

The $\mathrm{NO}_{\mathrm{x}}$ reduction observed was, therefore, consistent and substantial. It can be shown to be the result of the fuel volatility, the way the volatiles are released from the sawdust in a combustion environment, and the way in which the nitrogen is released from the sawdust in a combustion environment.

\section{Mercury Emissions Reduction}

Mercury emissions also are reduced by cofiring. Testing of mercury concentrations in coal at Albright Station for the Toxic Release Inventory during 1999 and 2000 show some variability in the fuel, however they show an average mercury concentration of $0.18 \mathrm{mg} / \mathrm{kg}$ or ppmw in this fossil fuel (dry basis fuel). The sawdust burned at Albright was tested for mercury concentration, and it shows 0.003 $0.009 \mathrm{mg} / \mathrm{kg}$ (dry basis fuel). Cofiring, then, can contribute significantly to a reduction in this emission.

\section{Greenhouse Gas Emissions}

Greenhouse gas emissions are also reduced by cofiring. The practice of firing 10 percent (mass basis) sawdust with coal is equivalent to firing 6 tons/hr of biomass. Firing 6 tons/hr of sawdust directly reduces fossil $\mathrm{CO}_{2}$ emissions by 6.3 tons/hr and, if methane generation from disposed of biomass is included, the total fossil $\mathrm{CO}_{2}$ equivalent reduction is $\sim 19$ tons/hr. Extrapolated over an entire year, the direct reduction of fossil $\mathrm{CO}_{2}$ emissions would be on the order of 27,500 tons/year and the total fossil $\mathrm{CO}_{2}$ equivalent reduction would be on the order of 82,500 tons/year.

\section{Conclusions and Expectations}

The test program at the Albright Generating Station, to date, has demonstrated that substantial $\mathrm{NO}_{\mathrm{x}}$ reduction can be achieved cofiring sawdust with coal in pulverized coal boilers when using separate injection technologies. This decrease in $\mathrm{NO}_{\mathrm{x}}$ emissions can come without experiencing increases in opacity or $\mathrm{CO}$ emissions. It can come while simultaneously experiencing the expected reductions in $\mathrm{SO}_{2}$ emissions.

Future testing at Albright Generating Station, and testing at Willow Island Generating Station, will provide more extensive documentation concerning the impact of cofiring biomass with coal on airborne emissions. All evidence available points to the expectation that the trends in $\mathrm{NO}_{\mathrm{x}}$ reduction will continue to be measured at both locations. 


\subsection{EXPECTED TECHNICAL PROGRESS DURING THE SIXTH PROJECT QUARTER}

The fifth project quarter, from October 1, 2001 through December 31, 2001 is expected to see the following progress, as shown in Table 2.

Table 2. Anticipated Progress at Willow Island and Albright Demonstration Sites

\begin{tabular}{|l|l|}
\hline \multicolumn{1}{|c|}{ Progress at Willow Island } & \multicolumn{1}{c|}{ Progress at Albright } \\
\hline Completion of Construction & 100-Hour testing of the cofiring system \\
\hline Baseline Testing & $\begin{array}{l}\text { Completion of the 720 test hours of cofiring at } \\
\text { various loads }\end{array}$ \\
\hline Initial Startup and Shakedown Testing & $\begin{array}{l}\text { Final report on cofiring at Albright Generating } \\
\text { Station to Allegheny Energy Supply Co. }\end{array}$ \\
\hline $\begin{array}{l}\text { Short term testing of cofiring sawdust and trifiring } \\
\text { sawdust and TDF with coal }\end{array}$ & $\begin{array}{l}\text { Preparation of a paper for the 27 International } \\
\text { Coal Utilization Conference-the Clearwater } \\
\text { Conference }\end{array}$ \\
\hline $\begin{array}{l}\text { Preparation of a paper for the } 27^{\text {th }} \text { International } \\
\text { Coal Utilization Conference- the Clearwater } \\
\text { Conference }\end{array}$ & \\
\hline
\end{tabular}

